\title{
An emphasis on the leadership role of the man in context of family and church in a post-pandemic era: A qualitative analysis
}

\author{
Dr Arthur John Alard \\ International College of Bible and Missions \\ Roodepoort South Africa \\ Email: principal@icbm.ac.za \\ Orcid ID http://orcid.org/0000-0003-0572-2769 \\ Professor Fazel Ebrihiam Freeks \\ Faculty of Theology, North West University \\ Potchefstroom South Africa \\ Email:10589686@nwu.ac.za \\ Orcid ID http://orcid.org/0000-0002-2474-8756
}

DOI: http://doi.org/10.46222/pharosjot.1027

\begin{abstract}
The leadership role of the man has significant impact on the wellbeing of the family and church, which, in turn, has a significant impact on society. This article encompasses an evaluation of the leadership role of the man in context of the family and church, with an analysis of qualitative research through structured interviews (naïve sketches) conducted with fifteen female participants. The structured interviews are presented in the form of selected verbatim responses to five questions related to the leadership role of the man in the mentioned contexts. It is imperative for men to study the Bible adequately and appreciate the authority of Scripture and what it says about their leadership role in the family and church. Having a sound biblical theology about the leadership role of the man in context of the family and church can potentially help him to lead his family and church toward a more biblical model of leadership in a post-pandemic era. The purpose of this article is to highlight the imperative leadership role of the man, where challenges may be identified, and practical solutions be recommended for equipping men to be effective leaders in the mentioned contexts. This article comes from a chapter in a larger study from a PhD dissertation: The leadership role of the man in context of the family and church: A Pastoral-Theological study.
\end{abstract}

Keywords: man, father, husband, church leader, equipping, post-pandemic.

\section{Introduction}

The leadership role of the man has significant impact on the wellbeing of the family and church which, in turn, has a significant impact on society. But this does not mean that women do not have a significant impact in society. Many authors and researchers view Ephesians 5:22-33 as a patriarchal view of a marital relationship of ruling the wife. Ruling the wife is not the emphasis in this paper because to rule as husband, father and leader is detrimental to the family and church (Ademiluka, 2021). The authors of this article rather view the leadership role of the man as being supportive, cooperative and in collaboration with the wife or mother for the progress and growth of families. Stringer (2009) asserts that there is a great offensive by Satan against 'fathers and families in our societies.' He gives examples from statistics that demonstrate that there is a void of leadership within the family because the situation with the next generation seems to be worsening. Stringer (2009) avers that:

- Half of our marriages end in divorce.

- Millions of children live in fatherless homes. 
- More than one child in eight is raised on government welfare.

- A total of $18 \%$ of children live in poverty.

- Teenage sexual activity will result in nearly one million pregnancies annually, leading to:
- 406,000 abortions.
134,000 miscarriages.
490,000 live births.
- Three million teenagers will get sexually transmitted diseases within the year.

The statistics above are certainly grim. Research results all confirm one problem - the family is in crisis. Societies are in crisis because the family is in crisis, which is an indication that the church is struggling at its role to minister to families effectively on a proactive level (See Freeks et al., 2015; Morley and Delk, 2004; Padi, et al., 2014). In addition, and to the extreme, society refers to men as trash and not leaders (Shahvisi, 2019).

Clark (2011) stresses the importance of the presence and active involvement of both parents in the lives of their children, but especially the father. He avers that the leadership role of the father in the lives of his children has a lasting impact on how they develop spiritually and in understanding who God is in relationship to them. Furthermore, 'intentional involvement' by the father increases the kind of influence that he has on his children. Clark (2011) additionally avers that children whose fathers are not intentionally involved in their lives generally 'are developmentally disadvantaged in many areas'. In Ephesians 5:21-6:4 Paul speaks directly to men regarding their leadership role in the family, since they are responsible 'to take the lead in exemplifying Christian unity as they discipline and instruct their children in the Lord' (Clark, 2011).

Leadership development in a post-pandemic era in the church will continue to be challenging. Verster (2020) avers that the COVID-19 virus has impacted the way the church functioned during the lockdown where people were not able to attend church gatherings and thus resorted to 'online, services, online prayer meetings, and online visits.' Verster (2020) rightly observes that 'Koinonia is under a great deal of stress.' If equipping men for their leadership role in the family and church was challenging in the past, then these experiences ought to have taught church leaders by now how to adapt during a crisis to adequality equip men in the mentioned contexts.

The central theoretical argument of this study is that there are challenges affecting men in their leadership role in the family and church, and that these may be resolved through identifying biblical principles which serve as guidelines for equipping men in their leadership role in the family and church. This is a critical issue in lieu of the need for the effective functioning of the family and church in a post pandemic era.

\section{Leadership defined}

The lack of effective leadership could lead to a void of 'genuine leadership' in family and church which could open the door for people to be deceived in the sense of yearning for someone to lead them (Blackaby \& Blackaby, 2011). With so many different definitions and descriptions of a leader and leadership in general, the most concise definition was given by Maxwell (1993) who described it in this way: 'Leadership is influence. That's it. Nothing more, nothing less.' Further definitions are those of Finzel (1994) and Ngaruiya (2017) are identical to Maxwell's assertion that leadership can be defined in one word: 'Leadership is influence.' Finzel (1994) avers that 'anyone who influences someone else to do something has led that person.'

Maxwell (1993) avers that one of the problems with the way people think about leadership is that they describe it 'as the ability to achieve a position, not to get followers.' Maxwell (1993) quotes James C. Georges as one who has given the clearest definition of leadership: 'Leadership is the ability to obtain followers.' Maxwell (1995) avers that it 'takes a leader to attract a leader', and that leaders have followers for the purpose that mentoring can take place; 
as this takes place, the leader 'multiplies his effectiveness' through the mentoring of his followers, who are ultimately potential leaders.

The effective leader is ultimately one who is able to attract other leaders with the purpose of multiplication of leadership so that responsibilities are shared, and burnout prevented. Malphurs' (2003) sentiment dovetail with those of Maxwell: 'leadership can't happen without followers or supporters.' In any group of people or organization, if no one is following, then there is no leader. The same is true in the family and the church. Effective leadership leads to effective functioning families, churches, and communities. Ngaruiya (2017), Malphurs (2003), Maxwell (1993) and Finzel (1994) all affirm that influence is central to the way leadership is defined.

\section{Servant Leadership}

Selfishness and inflated egos lead to toxic attitudes and behaviours that contradict servant leadership. It was Robert Greenleaf (1998) who first brought the concept of servant leadership to the fore by taking two words that seemed quite opposed to each another - 'servant' and 'leader' to make up 'servant leader' (Spears, 2010). The concept of servant leadership is very ironic because it is the very characteristic that is required of all leaders.

After many years of studying Robert Greenleaf's essays on servant leadership, Spears (2010) was able to identify ten critical characteristics which every servant leader ought to have and develop in whatever context he or she occupies:

1. Listening: Leaders have traditionally been valued for their communication and decision-making skills. Although these are also important skills for the servant leader, they need to be reinforced by a deep commitment to listening intently to others.

2. Empathy: The servant leader strives to understand and empathize with others.

3. Healing: One of the greatest strengths of servant leadership is the potential for healing one's self and one's relationship to others.

4. Awareness: General awareness, and especially self-awareness, strengthens the servant leader. Awareness helps one to understand issues involving ethics, power, and values.

5. Persuasion: Another characteristic of a servant leader is reliance on persuasion, rather than on one's positional authority in making decisions with an organisation. The servant leader seeks to convince others, rather than coerce compliance.

6. Conceptualization: The ability to look at a problem or an organization from a conceptualizing perspective means that one must think beyond day-to-day realities. Servant leaders are called to seek a delicate balance between conceptual thinking and a day-to-day operational approach.

7. Foresight: Foresight is a characteristic that enable the servant leader to understand the lessons from the past, the realities of the present, and the likely consequence of the future.

8. Stewardship: Servant leadership, like stewardship, assumes first and foremost a commitment to serving the needs of others. It also emphasizes the use of openness and persuasion, rather than control.

9. Commitment to the growth of people: Servant leaders believe that people have an intrinsic value beyond their tangible contributions as workers. The servant leader recognizes the tremendous responsibility to do everything in his or her power to nurture the personal and professional growth of employees and colleagues.

10. Building community: The servant leader senses that much has been lost in recent human history as a result of the shift from local communities to large institutions as the 
primary shaper of human lives. This awareness causes the servant leader to seek to identify some means for building community among those who work within a given institution. Servant leadership suggests that true community can be created among those who work in business and other institutions.

Liden et al. (2014) claim that the concept of servant leadership 'is unique among leadership approaches' because it places a 'strong emphasis on leading by serving followers.' Greenleaf (1998) avers that the concept of 'servant' is foundational 'in our Judeo-Christian heritage'. He observes that even though there are thousands of references of the terms 'servant,' 'serve' and 'service', there is unfortunately evidence that we live in a 'low-caring society' even when resources are not a factor. In this regard, Greenleaf (1998) claims that there are those who have an abundance of resources at their disposal but are not good stewards in using those resources to serve others. Greenleaf (1998) acknowledges that there are people who do serve others but laments that it seems like those people are "losing ground to the neutral or nonserving people.'

Greenleaf (1998) suggests asking the following questions to determine whether someone is a servant leader, namely: 'Do those being served grow as persons: do they, while being served, become healthier, wiser, freer, more autonomous, more likely themselves to become servants?' Greenleaf's (1998) questions affirm that a servant leader does not just accumulated followers, rather his or her role is to develop and nurture followers into servant leaders. Spiritual leadership comes into focus in this study since it overlaps with leadership in the family and church. Spiritual leaders are not chosen by the will of man but by God. It should also be understood that God keeps all leaders accountable in the role to which he has called them (Sanders, 1994; Wiersbe, 2011).

\section{Research Methodology}

Osmer's (2008) descriptive-empirical task was used as a research methodology. The descriptive-empirical task involves priestly listening, a key element when it comes to how the data for this research was collected from participating respondents (see Osmer, 2008). The research method used for gathering data was in the nature of qualitative design (structured interviews/ naïve sketches) which encompassed fifteen female participants from five selected evangelical churches in Johannesburg, South Africa. Permission and ethical clearance to conduct qualitative research with participants was granted by the following stakeholders:

- Theology Research Ethics Committee (TREC), North-West University, Potchefstroom campus on 28/01/2019.

- Church leaders from five selected evangelical churches/ councils gave permission for questionnaires to be conducted among their church members.

- Weltevreden Chapel - Roodepoort Gauteng (29/11/2018).

- Evangelical Bible Church of Southern Africa - National Council, Johannesburg Gauteng (10/12/2018).

- Africa Evangelical Church Westrand, Roodepoort North Gauteng (9/12/2018).

- El Shammah Evangelical Church (Evangelical Church in South Africa) Glenvista Gauteng (6/12/2018).

- Brethren in Christ Church - South Africa, Braamfontein Gauteng (14/12/2018).

- Individual participants: each participant gave their permission to voluntarily participate in the research by signing a consent form.

\section{Sample and population}

A representative church leader from each church was asked to identify and select potential female volunteers suitable for participation in the research. Church members were contacted in person at their churches and by telephone to make appointments for the time and place where the structured interviews would be completed. The information that was in the letter 
regarding anonymity, confidentiality, risks, withdrawal and termination were clearly communicated to all participants verbally and in written format.

\section{Discussion}

The participants were asked five open-ended questions related to the leadership role of the man in context of family and church. The purpose of the naïve sketches was to identify common themes around the feedback from participants and demonstrate the validity of those responses by correlating them with extant literature.

The following five open-ended questions formed part of the naïve sketches:

1. In your view, in what ways will the church be negatively impacted when it does not follow the biblical guidelines for appointing deacons and elders in the church?

2. In your view, what are the main factors that have caused men to not function adequately as leaders in the context of family and church?

3. According to you, why is it important for the man to function as the head and spiritual leader in the family?

4. According to you, in what ways are men and women equal in value before God, and how do they have distinct roles?

5. According to you, how do you think men should be equipped for the leadership role in the context of family and church?

\section{Demographic information}

Table 1:

Age

\begin{tabular}{|l|l|l|}
\hline Age & Frequency & $\%$ \\
\hline $20-30$ & 2 & 13.3 \\
\hline $31-40$ & 6 & 40.0 \\
\hline $41-50$ & 4 & 26.7 \\
\hline $51-60$ & 1 & 6.7 \\
\hline $61-70$ & 2 & 13.3 \\
\hline Total & 15 & 100 \\
\hline
\end{tabular}

Table 1 shows that most participants (66.7\%) were in the 31-50-year-old age group. The youngest group made up $13.3 \%$ of participants who were between the ages of 20-30. The oldest group made up 20\% of participants who were between the ages of 51-70.

Table 2:

Ministry Activity

\begin{tabular}{|l|l|l|}
\hline Ministry Activity & Frequency & $\%$ \\
\hline none & 3 & 20.0 \\
\hline Women & 5 & 33.3 \\
\hline Youth/children & 4 & 26.7 \\
\hline Worship/music & 3 & 20.0 \\
\hline Total & 15 & 100 \\
\hline
\end{tabular}

Table 2 shows that most participants (80\%) indicated that they were involved in ministry activities at their churches. Only $20 \%$ of participants did not indicate any ministry involvement.

Table 3:

Family Status

\begin{tabular}{|l|l|l|}
\hline Family Status & Frequency & $\%$ \\
\hline Married and parent & 11 & 73.3 \\
\hline Married & 1 & 6.7 \\
\hline Single & 3 & 20.0 \\
\hline Total & 15 & 100 \\
\hline
\end{tabular}

Table 3 shows that most participants $(73.3 \%)$ were married with children. Of the remaining participants, $6.7 \%$ were married with no children, and $20 \%$ were single with no children. 
Table 4:

Education

\begin{tabular}{|l|l|l|}
\hline Family Status & Frequency & $\%$ \\
\hline Grade 11 and below & 2 & 13.3 \\
\hline Grade 12 (Matric) & 6 & 40.0 \\
\hline Higher Certificate & 1 & 6.7 \\
\hline Diploma & 2 & 13.3 \\
\hline Bachelor of Arts / Science & 4 & 26.7 \\
\hline Total & 15 & 100 \\
\hline
\end{tabular}

Table 4 shows that most participants $(46.7 \%)$ had a tertiary education level. Only $13.3 \%$ of participants indicated that they achieved Grade 11 or below, and $40 \%$ of participants indicated that they achieved a Grade 12 (matric) school leaving certificate. From this data one observes that most of the female participants are well educated.

The following five themes and related sub-categories emerged from the data analysis around the responses of participants.

\section{Theme 1: Authority of Scripture}

The authority of Scripture emerged as one of the most dominant themes in the responses related to the importance of understanding the leadership role of the man in the two contexts. Participants accentuated the value of men studying the Scriptures and the significant role of the Holy Spirit when it came to making leadership decisions, especially in the context of identifying and appointing men to serve as deacons and elders.

Caution was expressed by participants regarding church leaders who do not follow biblical guidelines for appointing new church leaders. They warned of the pending danger that the church would be leaderless from a biblical perspective and could, as a consequence, fail. Their express fear was that false doctrines might creep into the church because individuals were appointed who did not fit the biblical qualifications for leading the church. MacArthur (2008) avers that deacons and elders are equally qualified in terms of their 'character and spiritual life' and that the only recognizable difference between the two is that the elder must have the ability to teach, whereas this is not a requirement for deacons, and does not mean that they are 'less spiritually qualified'.

Table 5 below, presenting 1 Timothy 3:2-7, Titus 1:6-9 and 1 Peter 5:1-3, illustrates a comparison of the characteristic qualifications for the man to serve as an elder in the church. These illustrate the quality of characteristics that the Apostles Paul and Peter taught the church to look for in the men that were to serve in the important role as elder.

Table 5:

Comparison of Elder qualifications

\begin{tabular}{|l|l|l|}
\hline 1 Timothy 3:2-7 & Titus 1:6-9 & 1 Peter 5:1-3 \\
\hline 1. Above reproach & 1. Above reproach & $\begin{array}{l}\text { 1. Not under compulsion, but } \\
\text { voluntary }\end{array}$ \\
\hline 2. The husband of one wife & 2. The husband of one wife & $\begin{array}{l}\text { 2. Not for sordid gain, but with } \\
\text { eagerness }\end{array}$ \\
\hline 3. Temperate & 3. Having children who believe & $\begin{array}{l}\text { 3. Nor yet as lording it over...but } \\
\text { proving to be examples. }\end{array}$ \\
\hline 4. Prudent & 4. Not self-willed & \\
\hline 5. Respectable & 5. Not quick tempered & \\
\hline 6. Hospitable & 6. Not addicted to wine & \\
\hline 7. Able to teach & 7. Not pugnacious & \\
\hline 8. Not addicted to wine & 8. Not fond of sordid gain & \\
\hline 9. Not pugnacious & 9. Hospitable & \\
\hline
\end{tabular}




\begin{tabular}{|l|l|l|}
\hline 10. Gentle & 10. Lover of what is good & \\
\hline 11. Uncontentious & 11. Sensible & \\
\hline 12. Free from the love of money & 12. Just & \\
\hline 13. Manages his household well & 13. Devout & \\
\hline 14. Not a new convert & 14. Self-controlled & \\
\hline $\begin{array}{l}\text { 15. A good reputation with } \\
\text { those outside the church }\end{array}$ & & \\
\hline
\end{tabular}

Adapted from Strauch (1995:73)

Theme one showed two specific sub-category findings: the value of studying the Scriptures and biblical principles for appointing leadership.

\title{
The value of studying the Scriptures
}

Most participants commented on the value of studying the Scriptures and using this as the guiding principle for appointing leaders for the church. Participant A commented:

\begin{abstract}
everything that is written in the Bible it was or it is motivated by the Holy Spirit. So why would we call ourselves Christians if we do not follow what the Bible says on how \& what we should do as Christians...2 $2^{\text {nd }}$ Timothy $3: 16-17$. We also need to follow the biblical guidelines, because it is profitable for doctrine, for reproof and for correction.
\end{abstract}

Participant $\mathrm{C}$ commented on the importance of men studying the Scriptures, especially considering their role as the spiritual leader in the family and in the church. She said: 'They [men] need to study and understand the Word of God.'

According to Paul in Ephesians 5:2, it is the husband's responsibility to act in the best interest of his wife. Hughes (2006) avers that the husband 'is to be a man of the Word who lives a godly life, praying and sacrificing for his wife.' If the husband refrains from studying and understanding the Word of God, it will be impossible for him to function in his spiritual leadership role to guide the spiritual maturing of his wife and he would be unable to teach and act as an example for his children if he were biblically illiterate (see Deuteronomy 4:9; 6:7; $11: 13-21)$. A recent study confirmed that there is a disturbing trend of biblical illiteracy within the evangelical churches in South Africa (Smith, 2013).

\section{Biblical principles for appointing leadership}

If church leaders do not submit to God's order and his Word, how can leaders expect congregants to submit to their authority as leaders? This will further cause confusion within the church. Malphurs (2005) affirms the need for church leadership to be trustworthy: he says that 'you cannot lead people who do not trust you!' Participant A commented:

\section{Order is vital within the church. We worship a God of order. Leaders need to be appointed to hold the church accountable in their behaviour (heart attitude) and spiritual growth. If a leader does not adhere to the biblical principles for appointing leaders, they will not understand their role and could become self- serving instead of glorifying God.}

Most participants clearly communicated their views of the responsibility of church leadership to follow biblical principles. Participant D commented: 'The men in leadership roles in the church are to be leaders edifying the church. If they do not follow God's word concerning the church, then that will be the downfall of the church.'

Most participants agreed that the church needs to follow biblical guidelines when they appoint deacons and elders for the church. Participants noted, however, that church leaders did not consistently follow biblical requirements and hence the church suffered because unqualified deacons and elders were appointed in leadership roles. Participant $F$ provided an example asserting that church leaders appointed '... men who are not ready for leadership and not spiritually mature enough to lead and guide the church. Biblical guidelines are there so 
candidates are chosen based on biblical criteria in order to perform the roles of a deacon or elder.'

Participant $\mathrm{N}$ also noted with concern that not following biblical guidelines for appointing leaders 'Could lead to false teachings within the church.' She continued by posing a vital question: 'How could a deacon or elder that isn't appointment correctly be capable of leading the church in a way that is biblically correct? They are the example for the church and therefore should do things as correctly as possible.'

These comments are honest observations made by women within the selected evangelical churches regarding the leadership practices for appointing deacons and elders. MacArthur (2008) affirms that the church must follow biblical guidelines for appointing church leaders, especially as it relates to deacons and elders. He asserts that 'the church must not choose elders merely because of their knowledge of the business world, their financial ability, their prominence, or even their innate ability to lead others;' rather, they should 'meet the biblical qualifications.'

Not all participants held to a complementarian perspective. Participant $\mathrm{K}$ said: 'I think one aspect is to realize that leadership should not be exclusive to men. Both men and women should be considered for leadership depending on individual strengths and aptitude.' Participant K's comment is true regarding leadership positions in the church, except for the role of elder. Participant K's view may be in line with an egalitarian perspective or even what Grudem and Piper (1991) and Grudem (2006) call 'evangelical feminism.' Grudem (2006) avers that Scripture clearly limits the office of the elder to male leadership and that there are many other ministry opportunities for women while church leaders should spare no effort to make those ministry opportunities available to women.

\title{
Theme 2: Equality of Men and Women
}

Most respondents held the view that men and women are equal before God. The differences occurred around details when they explained the various ways in which they understood these differences. These differences were clearly demonstrated in a variety of views regarding the distinct roles of men and women when they function in family and church. Frame (1991) affirms that 'women and men equally image God, even in their sexual differences, even in their differences with regard to authority and submission'. The overwhelming majority of participants held to a complementarian perspective of the role of men and women in context of family and church.

This theme presented two specific sub-category findings: first, equal in value, and second, distinct roles.

\section{Equal in value}

The work of Neuer (1991) dovetails neatly with the majority feedback from participants when he asserts that 'The Christian view of the sexes starts from the premise that both men and women are in every respect God's creatures and of equal value'. Participant D commented:

\begin{abstract}
'Men and women are equal in God's eyes. They are both responsible for the nurturing and upbringing of their children. They complement one another. Both play a part in bringing up their children in the ways of the Lord.'
\end{abstract}

Ortlund Jr. (1991) avers that 'both male-female equality and male headship, properly defined, were instituted by God at creation and remain permanent'. Male-female equality and male headship cannot be driven by emotions, societal pressures or biased interpretation of the Scriptures. 


\title{
Distinct roles
}

Most participants agreed that men and women have distinct roles within family and church. Participant E commented: 'God created women to be a help mate to her husband.'

Participants I and $O$ made the important observations that the wife is not just one who agrees with everything that the husband says and does but, instead, that her equal value in the marriage relationship stems from the fact that God created her to be a responder, that she thus is required to respond to her husband's leadership, ultimately serving as a 'sounding board' for him, not as a 'silent doormat'. Ortlund Jr. (1991) affirms that wives are helpers who respond to their husbands and that they complement each other on an equal basis in family and church. Participant I commented: 'Women were made to support their husbands and to offer or serve as a sounding board.' Participant O commented:

\begin{abstract}
I did not understand this before I came to know the Lord, but since then I understand that just as Jesus is the head of the church, there must be godly men leading and in turn, godly men leading and guiding the family. It is important to understand that this does not mean the man can do or say as he pleases, and the wife must blindly follow and does not mean that the wife must be a doormat. Rather the wife must understand this role before getting married.
\end{abstract}

Ortlund Jr. (1991) argues that men and women are equal in 'personal worth', but that they are not equal in 'personal roles'. Men are the leaders and women support them in their leadership role in both the two contexts. The distortion of gender roles can be catastrophic to the wellbeing of the family, church and community in a variety of ways. Grudem (2006) avers that the distortions of roles can come from husband or wife in the following ways, centring on 'aggressiveness or passivity':

- Errors of aggression are those that have their beginnings in Genesis 3:16:

$\circ$ The husband can be selfish, harsh, domineering, or tyrannical. This is not biblical headship.

- On the other hand, if the wife resists the husband's leadership by trying to usurp it, then she is not following God's pattern for marriage.

- Opposite to errors of aggression are those of passivity. They are equally wrong:

- When the husband abdicates his leadership responsibilities by not discipling his children, not caring for the family's physical or spiritual needs or not defending his wife or children when verbally attacked by a friend or relative (these are just a few examples), then his acting as a wimp does not fit the role God designed for him in marriage.

- Or when a wife chooses not to participate in family decisions, does not express her preferences or opinions, does not speak up when her children or husband are doing wrong or does not object to her husband's physical or verbal abuse, then she is not being submissive, but instead is acting as a doormat, which is out of line with the role God designed for her in the marriage relationship.

Grudem (2006) has given a clear explanation of the way that God designed gender roles in the family and particularly in the marriage relationship. These have however been distorted in many ways and have hurt the family and more specifically marriages. It is important for the church to equip families and particularly men and women to understand the biblical perspective of the role of the man and woman in the family and marriage relationship.

\section{Theme 3: Leadership in the Family}

Most participants affirmed the importance of the man being the leader in the family and that he has a God-given responsibility to fulfil this role. However, Participant N's perspective of the 
unimportance of the man's leadership as head in the family is an indication of the influences of society where the Scriptures are not held in high regard. Participant N said: 'I don't think it is important for the man to be the head of the family. Women are just as capable to lead the family as a man is.'

Theme three has three specific sub-category findings: head of the family, role of the husband and role of the father.

\section{Head of the family}

Most participants agreed that the man is the head of the family and that it comes with a considerable responsibility for the man to sacrificially love and provide for his family. Ortlund Jr. (1991) states: 'Evangelical feminism argues that God created man and woman as equals in a sense that excludes male headship.' This view reconstructs God's order in family and church and will cause confusion, first in the family, then the church, then the community. Participant A commented that the '... role of a man is to be the head of the family to love his wife \& provide. A role of the woman is to submit \& be a helper.' Participant B commented: 'We are one before God in our faith and love for God. Men are always the head of the church and home. Women are always on the side of supporting their husbands. God is always the centre of everyone's life.'

Male headship is a sensitive topic as it encompasses the debate of the leadership role of the man not only in the context of marriage but also in the context of organizational leadership. Ortlund Jr. (1991) gives one of the most clearly articulated definitions of male headship: 'In the partnership of two spiritually equal human beings, man and woman, the man bears the primary responsibility to lead the partnership in a God-glorifying direction'. The Greek word for

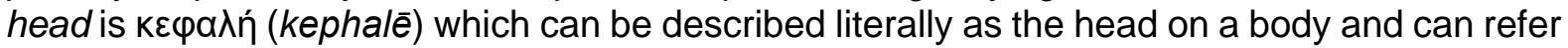
to 'being of high status' and having authority over something or someone, particularly in the following contexts: the husband is the head in relationship to his wife (1 Corinthians 11:3b; Ephesians 5:23a) and Christ is the head in relationship to his Church (Ephesians 4:15; 5:23b; Colossians 1:18) (see Danker, 2000; Hoehner, 2002; Hoehner 2000; Thielman, 2010).

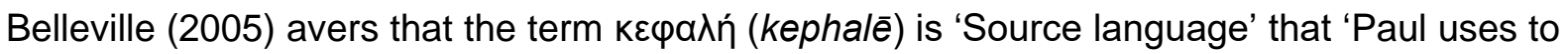
describe the theological relationship between Christ and his bride, the church (Ephesians 4:15-16; Colossians 2:19, "from"), and between a man and a woman (1 Corinthians 11:8, "from"; Eph 5:30, "of one flesh and of his bones" KJV)'. Hamilton (2000) poses a view that dovetails with Belleville's of $\kappa \varepsilon \varphi \alpha \lambda n$ (kephalē) as a rare usage of the word 'head' in 1 Corinthians 11:3 to refer to the possibility of the man being a leader over the woman in the

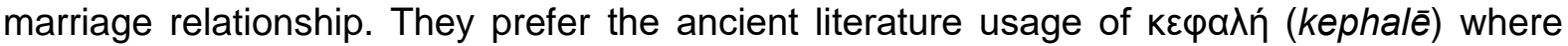
'head' means 'source' or 'origin,' not leader because, for them, this removes from the text the problem they have with male headship. Hamilton (2000) provides an alternative reading of 1 Corinthians 11:3 where the term 'source' is preferable: 'Now I want you to realize that the source/origin of every man is Christ, and the source/origin of a woman is the man, and the source/origin of Christ is God.'

The problem with the 'Source language' proposed by Belleville (2005), and Hamilton (2000) is that it negates the metanarrative in Scripture that God designed the man to be the head in the family over his children, who are commanded to obey both parents (Ephesians 6:1-3), and his wife, who is commanded to submit to her husband (Ephesians 5:22-24). Snodgrass (1996)

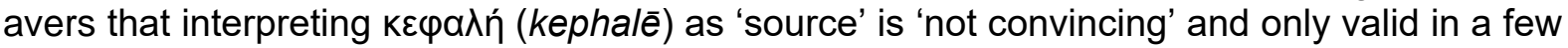
instances in extra-biblical texts. He gives a good example of how the use of 'source' as an

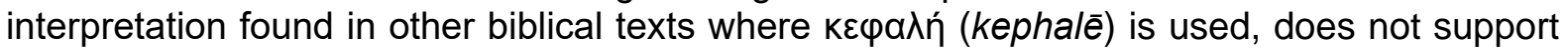
the meaning for 'source':

The use of kephalē in [Ephesians] 1:22 and Colossians 2:10, where the issue is the subjection of all things under Christ, precludes the idea of source as the meaning in those texts. Paul is not arguing that Christ is the source of the principalities and powers, but that He has authority over them. 


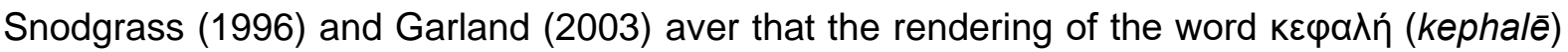
as 'source' is not the most accurate and is at best suspect. The reason why this meaning seems to be used by egalitarians to support their view regarding male headship is that it eliminates, as indicated, any notion of subordination on the part of the woman.

\section{Role of the husband}

The husband is the main provider for his family as a norm but the feedback shows that there is frustration that men come home from work and expect the wife to take care of the children and perform cleaning and cooking all on her own, while his excuse for not sharing the burden is that he has worked all day and is entitled to rest without being bothered. There are many women who are working, too, yet the expectation remains the same. This is a serious indictment on men, and it shows that there are men who do not understand their role as the head, husband and father in the family. Participant E commented: '... they (men) work almost the entire day and feel that they have done their part and the responsibility of the home/children should be taken care of by his wife'. Participant D commented on the importance of the man having 'The utmost respect for his wife'. In fact, the apostle Peter warns husbands that if they do not respect their wives God would not listen to, let alone answer, their prayers (1 Peter 3:7).

Grudem (2006) avers that the husband has the responsibility to sacrificially love his wife and not be harsh towards her (Colossians 3:18-19). The man is the leader of his wife and children and if they are not following him then he is just taking a walk on his own. That is not God's design for the family. Every family needs a leader: preferably, the husband/ father. That just as man is the head of the wife, Christ is the head of the Church (Ephesians 5:23).

Men are responsible for functioning within their God-given leadership role in the family and the church in a manner that brings glory to God by serving their family and the congregation with considerable care. Köstenberger and Köstenberger (2014) aver that 'while the man's headship in the home and the church entails authority, Scripture presents this authority within the context of the husband's or male church leader's care and responsibility':

- Husbands are to love their wives and care for them (Ephesians 5:25-30).

- Elders are to exercise their leadership in a way that's not domineering over those in their charge, but as examples to the flock (1 Peter 5:3).

- Leadership ought to be defined primarily as service and sacrifice for others (Mark 10:45; see also vv. 42-43).

\section{Role of the father}

Most participants agreed that men need to be role-models as fathers in their family so that they could model biblical manhood for their sons. This is a good observation regarding the importance of men passing down leadership skills and responsibilities by being good examples and being active in family and church. Participant $\mathrm{J}$ commented: 'There has to be male leaders so that they can pass this down to their sons' generation to generation'. Participant D commented that fathers need to be consistent in their discipline of their children and are responsible for teaching their children Scripture. She commented that the man must be: 'a good disciplinarian to his children bringing them up in the ways of the Lord.'

Participant I accentuated the importance of the man as a role model for his children and that he should be an example that his children should not ignore. In the context of the church refraining from following biblical guidelines for appointing leaders, participant I commented that the result would be that: 'There will be no male role models for our younger generation to look up to. The role of the male leaders in our church cannot be underestimated.'

Krampe and Newton (2006) aver that the man's leadership role in the family as father is essential for the healthy development of his children because his presence provides a stable, responsible and mature environment for them to thrive in. Warren (2005) avers that children 
who do not have a healthy relationship with their biological fathers find it difficult to identify with and relate to their heavenly Father. Both Krampe and Newton (2006), and Warren (2005) bring attention to the essential role that the man has as a father. His relationship with his children does impact their character development and relationship with God. Some of the character traits that the father ought to help develop in his children are: 'honesty, reliability, respect, obedience, responsibility, and duty' (Freeks, 2011). Other authors hold the same sentiment that fathers ought to recognize their God-given identity as leaders in the lives of their children and that they play an important role in the restoration of the family in the greater society (See Freeks \& Lotter, 2009; Williams, 2008).

Children will hopefully see their fathers' functioning as leaders in the family and church on a regular basis, because this will help them perceive the significance of the leadership role of the man in family and church and how they impact the positive functioning of the community. Unfortunately, 'absent and disinterested' fathers have a negative impact on children. The father plays an important role in developing biblical masculinity for his sons and biblical femininity for his daughters (Hardenbrook, 1991).

\title{
Theme 4: Leadership in the Church
}

Most participants affirmed that the leadership roles in the church are the responsibility of men, especially when it comes to the roles of deacon and elder. Some evangelical churches however do hold the view that women may serve as deaconesses in the church too. Theme four has two specific sub-category findings: the man's role as deacon and elder and the impact of society on gender roles.

\section{The man's role as deacon and elder}

Participant $D$ commented that men serving as deacons and elders must be willing to 'sacrifice their time and energy' and that they needed to have the biblical characteristics of leaders who are filling these positions: 'Be prepared to sacrifice your time and energy. They should have gentleness; this will help them deal with tough situations in a loving way. Not be quick to anger, it's harder to understand a situation when one is angry. Have a general open-mindedness.'

In the context of church leadership, Sanders (1994) affirms that the man must be a person who does not have any accusations against him, he should have a good reputation and demonstrate the biblical characteristics of one who desires to serve as a leader in the church. Participant $\mathrm{F}$ commented on her understanding of the equal value of men and women and their God-given distinct roles. She said that:

\begin{abstract}
Men and women are equal in that God love us equally, however in terms of roles in the church and home, they are different. Women do not preach and are not in deacon or eldership roles. In the home he is the head. Women are more the nurturers at home and support the men at home and at church.
\end{abstract}

Participant F's comments would be typically accepted within most evangelical churches, although not all evangelical churches would prevent women from preaching or serving as deacons. Many evangelical churches would also advocate for women to serve in leadership roles in the church other than that of the role of the elder/ pastor, which Scripture clearly identifies as being set aside for male leadership. For example, Payne (2012) identifies Phoebe as someone, specifically a female, as a deacon at the church in Cenchrea (Romans 16:1-2): he therefore asserts that women should not be excluded from any church leadership roles.

Participant N commented: 'Men do not follow/heed the instructions of God's Word. They shy away from their responsibilities of serving the church and its people they are more concerned about status than doing the will of God'. It may be that because women are eager to assume leadership roles in the church, Participants N's comments are true to the reality within the 
church, namely that men reject their leadership responsibilities easily because someone else is willing to perform these in their place.

Both the office of deacon and elder are important in the functioning of the church and does not mean that these leadership roles ought to be used to lord it over others. Instead, the purpose of these ministries is to "ensure that the true faith is maintained, true doctrine is disseminated everywhere, transgressors are admonished spiritually and restrained, and the poor and those in distress are helped and comforted according to their needs' (Breed, et al., 2008). Both men and women may serve in the ministry as deacon or deaconess, although the office of elder is restricted to men (Grudem, 2006; MacArthur, 2008; Schreiner, 2005; Blomberg, 2005; Breed, et al., 2008). Breed et al., (2008) correctly aver that 'there is no hint of a hierarchy of differences in status in the church as the body of Christ, or of men (including those in ordained ministries) belonging to a superior order from other members (eg women)'. In general, in the context of the value of persons in the body of Christ, one does not have higher status than another, they are always equal in value, yet regarding men and women in the church and family, they are equal in value and have distinct roles.

\title{
The impact of society on gender roles
}

Participant $\mathrm{K}$ noted the challenges that men faced in light of cultural pressures that he should be the sole bread winner. She commented:

\begin{abstract}
Men and women are equal before God. There are cultural distinctions between the roles that men and women should hold but these do not prove practical in all cases. E.g. Historically women are considered the caregiver to the children and the one who takes care of the home and the man is considered the breadwinner. This is not always practical especially in the current time where in many cases both men and women are employed fulltime.
\end{abstract}

It seems that the historical gender roles have been blurred because of societal realities. However, shared responsibilities in the family does not mean that the family is egalitarian by nature. Complementarity in the family dynamic requires that men lead by sharing the responsibilities in the home. What is biblical and practical works together well when the man leads well by understanding his responsibilities as the leader in the family and that he and his wife need to recognise their own societal realities and work together towards the common good for their family.

Marcoux (2018) avers that in 1982, 43\% of fathers admitted that they had never helped their wives to change the diaper of their infant children. Surprisingly, times have changed, and that number has dropped considerably to $3 \%$. These are good statistics that mean fathers are more involved in helping in the home with bathing, dressing, and changing diapers. Research has shown that the more the father is involved in these activities, the more it strengthens the father-child relationship in the growing years.

Participant $A$ commented on the male ego playing a role in the way men respond to societal leadership dynamics that may in turn have caused a negative impact on the way they lead or even decide not to lead in family and church. She commented: 'Now our days there's a lot of pressure on males/men. They cannot take the fact that a woman can be their superior or leaders workwise, education and therefore it demotivates most of them. Even their ego, selfesteem goes down.'

Blackaby and Blackaby (2011) aver that pride distorts the leader's reality and is a dangerous pitfall for their effectiveness. Men should not view 'themselves in distorted proportions' because pride can cause them to become, unteachable, self-sufficient, uncompassionate and vulnerable (Blackaby and Blackaby, 2011). Egotism is synonymous to pride, and men ought to be stable in their leadership role and responsibilities in family and church no matter what the situation is in the family, church, or society. 
Participant $\mathrm{J}$ holds to a complementary view but expressed her concern regarding the reality of passive men in the family and the church. She said that:

The church already has a larger number of women involved in ministry. If men are not appointed as deacons and elders, in my opinion women will start stepping into these roles. Men will no longer be a part of the church structure and women will lead. This is a problem as it is not how it was intended to be God's design.

Participant $O$ similarly commented: 'Society today sadly influences the church. The advancement of women in the feminist movement has had a huge impact within and outside the church. This has caused women, and to a lesser extent, men, to question the role of men and women in the family and the church.'

Neuer (1991) discusses the negative impact that feminism has on the church in seeking to reduce the number of men serving in leadership and looking to reconstruct the male leadership narrative in the church. He says that 'church feminism [...] is working for the maximum possible influence of women in church leadership and a revision of male-shaped theology.'

\section{Theme 5: Equipping Leaders}

Most participants agreed that men need training for leadership roles in family and church. The feedback from participants demonstrated that men were struggling and that their mothers, wives, sisters and daughters were noticing the challenges that they were facing around their leadership role in context of family and church. Theme five has three specific sub-category findings: mentors, involvement and education.

The COVID-19 social distancing restrictions had a major impact in the way the church facilitated its equipping ministries in 2020 and has continued into 2021. Due to the COVID-19 lockdown restrictions normal contact ministry activities like preaching, discipleship and mentoring were adjusted to adapt to ministry activities via social media platforms like Facebook, WhatsApp, and YouTube (Masonga, 2020). Masonga (2020) avers that the COVID-19 lockdown was a "necessary "evil" to reduce its impact' and that social media seems to have been a welcomed and useful resource in the interim for the church. The use of technology, however, only works well if all your church members have smartphones and access to the internet (Masongo, 2020). The use of social media may have been useful to some church members, but the church leaders need to make an effort toward a post-pandemic era of ministry by endeavouring to minister effectively to all its members, not just those who have access to technology.

\section{Mentors}

Participant $\mathrm{F}$ was the only one who explicitly said that the men who were considered for leadership had to be born-again Christians. This does not mean that others held the view that they did not need to be, but rather that this was implicitly communicated whereas participant F communicated it explicitly. She stated that they needed to be discipled, mentored and supported in the ministry. As a first and most important point, she commented that: 'Men should be saved. They should be mentored, and they should attend a course/training. Lastly, they should be supported'. Participant $\mathrm{J}$ noted that it is important for current leadership in the church to proactively mentor emerging leaders. She identified 'mentorship from current deacons and elders' as a means to equip men in their leadership roles. She said: 'Most of the leaders in our church has mentioned how the mentorship of past elders have taught them what they know.'

Freeks (2011) affirms the importance of mentoring, especially in the context of the family, but warns that mentoring 'should never prompt or provoke the idea of competition and domination.'In the African context studied here, mentoring can be an obstacle when current 
leaders are insecure about their leadership role at the church and see emerging leaders as a threat. Just as mentoring is important in the family, it is important in the church. Mentoring will provide a good framework for the men in the church to develop their leadership skills in a safe and encouraging environment.

\section{Involvement}

Participant $\mathrm{J}$ commented on men needing to be involved to a greater extent meaning that they needed more opportunities so that they could grow and become more confident in leading in the church. It is incumbent on church leaders to create these opportunities for the men that they are mentoring. She said that: 'Men should be offered [...] involvement in the ministries to assist them.' Malphurs (2005) affirms that involvement is a key element in building an effective ministry team. Church leaders need to understand that 'the church will only be as good as the people who make up the team...and that it takes good people to lead and build good churches.' The only way that men can grow into leadership roles in the church is if they are given opportunities to get involved.

\section{Education}

Most participants agreed that there was a need for training to be offered in the church, so that the men could grow and be able to lead well in family and church. Participant $\mathrm{J}$ commented: 'Men should be offered [...] education - some men have never been shown or taught on how to be a leader in the family or church.' Participant $\mathrm{O}$ commented: 'men are not properly equipped to understand and deliver on their role and do not lead by example. The homes and the church become disorderly and chaotic.'

Training should be provided primarily through the church and if someone desires further formal training they should be encouraged to do so. Malphurs (2005) asserts that Jesus gave His disciples the command 2000 years ago to go and make ('evangelize') disciples and to teach ('mature') them (Matthew 28:19-20; Mark 16:15; Luke 24:46-48; and Acts 1:8). Malphurs (2005) states that the end goal in the discipleship process is that the church does not just end up with a 'disciple, but a mature disciple.' This is the characteristic that the church should aspire when it comes to developing men in their leadership role in context of family and church. Mature men discipling and mentoring other men is more likely to produce mature men who would follow suit.

Participant B commented on the need for church leaders to understand the 'difference between leading and managing'. This would imply that church leaders need to understand this difference first so that they can teach it to the men they mentor for leadership. Maxwell (1995) avers that there is a considerable difference between leading and managing and that it is important for church leaders to understand the difference. Maxwell (1995) also avers that 'Some leaders forget to cast vision because they get caught up in managing. True leaders recognize a difference between leaders and managers. Managers are maintainers, tending to rely on systems and controls. Leaders are innovators and creators who rely on people' (Maxwell, 1995).

\section{Conclusion}

The responses of participants form an essential part of the central theoretical argument, which affirms that there are challenges affecting men in their leadership role in the family and church.

Firstly, in the context of the authority of Scripture, participants' responses focused on the value of men studying the Scriptures and the need for them to follow biblical guidelines when pursuing or appointing leadership in the church. Participants agreed that it was the responsibility of church leaders to hold Scripture in high regard, so that when it came to appointing leaders for the church, they would be following biblical guidelines as required. Participants focused their responses on the value of men studying the Scriptures and their 
dependence on the Holy Spirit when it came to making important decisions on behalf of the church. Participants expressed concern that improper appointments to church leadership could result in confusion and false teachings creeping into the church.

Secondly, in the context of the equality of men and women, participants focused their responses on equal value and distinct roles. Most participants held the view that men and women are equal in value before God but that they have distinct roles within the context of family and church. Participants clearly identified the man/ husband as the leader in the family and the church, and the woman/ wife as his helper, supporter and sounding board. They expressed that this did not mean that the man could do and say whatever he pleases, but rather that, as his helper and supporter in his leadership role in family and church, she serves as a responder, not a silent doormat.

Thirdly, in the context of leadership and family, participants focused their responses on the head of the family, the role of the husband and the role of the father. The responses showed that most of them believed that the man was ordained by God to serve as the head in the family. There was however a participant who commented that it was not important for a man to lead the family because a woman was just as capable to lead the family. Most participants agreed that the role of the husband/ father was to sacrificially love, care for, teach and provide for his wife and children. Participants emphasized that the husband was responsible for the utmost respect for his wife, and as a father he needed to be an example of a godly man for his children and be consistent in managing their discipline. Participants emphasised the shared responsibility that the husband and the wife enjoy in maintaining the home and nurturing their children.

Fourthly, in the context of leadership in the church, participants' responses focused on the man's role as deacon and elder and the impact of society on gender roles. Most participants agreed that the man should fulfil the role of deacon and elder in the church. However, one participant commented that men are not the only ones who should be considered for leadership roles in the church: women also ought to be given leadership roles based on their abilities. This is especially true as it relates to women serving as deaconesses in the church. Participants commented on the impact that society has on the leadership role of men in the church, specifically the influence of feminism regarding the appointment of female church leaders - particularly related to the role as an elder. They expressed concern for men who are passive in the church and, since there are many women in the church, they were likely to fill the gap that had been left there by present but passive men.

Fifthly, in the context of equipping leaders, participants' responses focused on mentors, involvement, and education. Most participants affirmed that the church was responsible for the training of men in their leadership role in family and church. They agreed that mentoring was an important methodology for equipping men, because those who had received mentoring from mature deacons and elders in the past demonstrated that they managed their leadership roles better than those who had not received any mentoring. They commented that part of developing competency in leadership meant that church leaders needed to give men more opportunities to be involved in ministry and for them to receive guidance in the process. Most participants agreed that education, whether formal or informal, was important for men as they endeavoured to grow in leading the church.

Finally, the overall feedback from participants indicated that they agreed that men were chosen by God to serve as spiritual leaders in family and church. The responses were not merely based on their cultural experiences or their emotions, but rather indicated that they held the authority of Scripture in high regard with a view to men leading the family and women supporting them in their leadership role in the two contexts. A future study in this context is recommended which may benefit the family and church by suggesting ways that women may support men in their leadership role in the mentioned contexts. 
Amidst moving toward a post-pandemic era of ministry, church leaders ought to see the value of incorporating technology to continue equipping men for their leadership role in the family and church. Social media technology is a useful resource for the church but should never be the primary equipping methodology for the discipleship and mentoring of men. The primary methodology for equipping men should be contact discipleship and mentoring which are core church ministries. The biblical model for discipleship should involve one-on-one sessions or ones with no more than twelve men meeting regularly for personal spiritual development, encouragement and accountability.

The figure 1 below illustrates Paul's four-generational discipleship model. 1) Paul discipled and mentored 2) Timothy and taught him everything he needed to know to be an effective leader in the church. Timothy thus became a disciple maker, discipling and mentoring 3 ) faithful men who would be competent to teach 4) others as well. What Paul entrusted to Timothy, Timothy entrusted to faithful men, who entrusted what they were taught to others, and so it spreads one person at a time, multiplying effective leaders for church and family. The family embodies the man's first disciples.

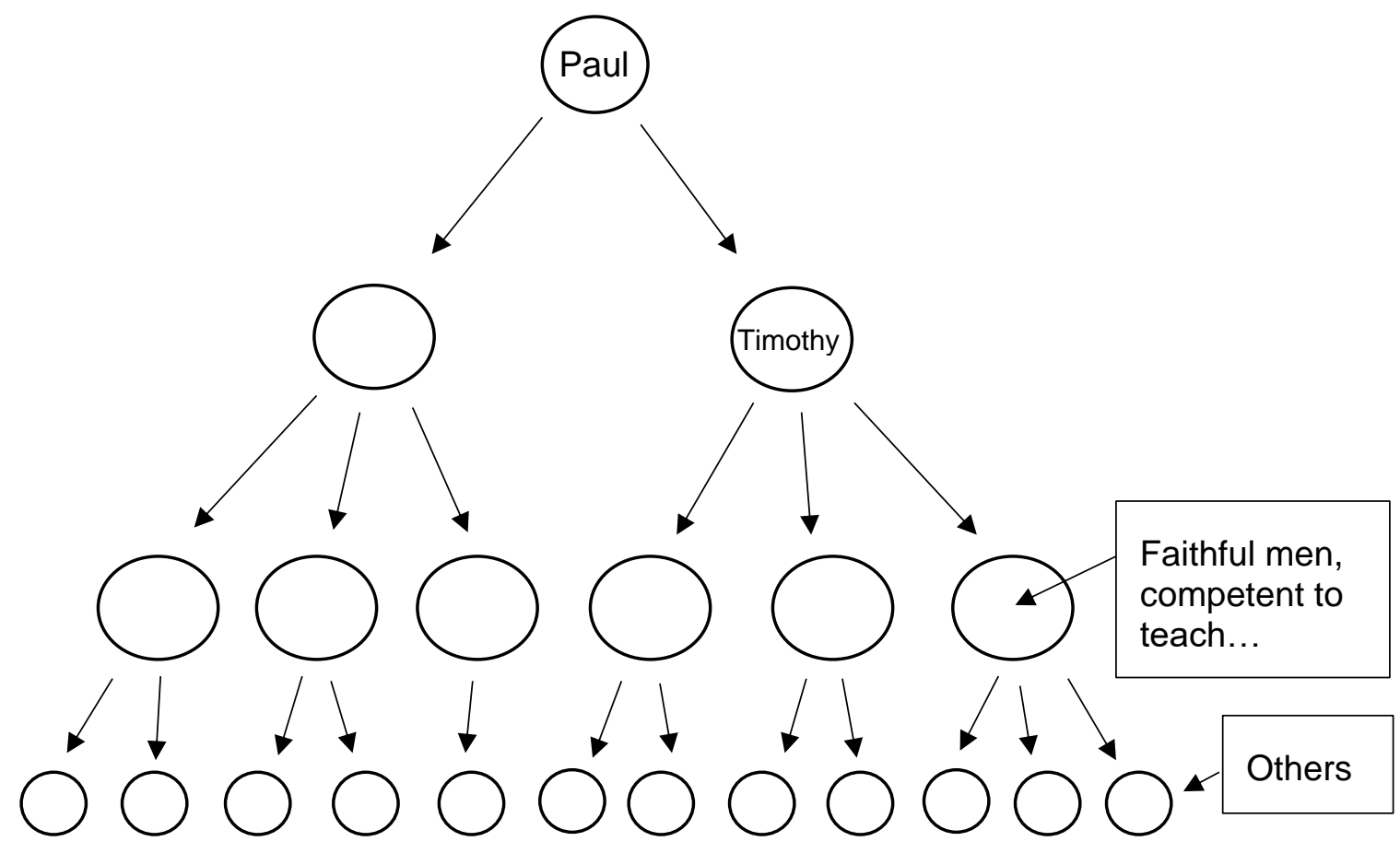

Figure 1: $\quad$ Paul's four generational levels of discipleship 2 Timothy 2:2

As more men are equipped by the church, a greater number of effective leaders will function in family and church. The church will therefore see a positive transformation in the men, women and children and this will impact the community. The kind of growth that equipping ought to bring in the life of the man is in the following areas (CCL, 2004:75-79):

- Liberality (Matt 5:42).

- Mercy (Matt 5:44).

- Contentment (Matt 6:25)

- Fellowship with other believers (2 Cor 6:14).

- Hope (2 Cor 4:16-18).

- Faith (Galatians 5:5-6).

- Temperance (Eph 4:19, 22-24). 
- Edification (Eph 4:29).

- Humility (Phil 2:3).

- Praise (Phil 4:4).

- Prayer (Phil 4:6).

- Contemplation and reflection (Col 3:2-3).

- Forbearance (Col 3:12-13).

- Industrious (2 Thess 3:10).

- Purity of Speech/Doctrine (2 Tim 2:16-17).

- Hospitality (Heb 13:2).

- Fidelity (Heb 13:4).

- Confession (James 5:16)

- Sympathy (1 Pet 3:8).

- Evangelism (1 Pet 3:15).

- Loyalty (1 Pet 4:8).

- Generosity (1 John 3:17).

- Love (1 John 4:16-19).

The biblical principles for growth listed above are areas in the life of the man that develops over time. That is, as he continues to submit his life to God in fellowship with other believers who would mentor him, and as he does the same for other men who requires discipleship and mentoring, this growth will be inculcated. The hope is that the church will implement what is already a pastoral-theological model for training men as found in Paul's 2 Timothy 2:2, that is, as indicated, the four-generational discipleship model for training all believers.

\section{References}

Ademiluka, S.O. (2021). For the husband is the head of the wife: A contextual re-reading of Ephesians 5:22-33 among Nigerian Yoruba Christians, In die Skriflig, 55(1), a2613.

Belleville, L.L. (2005). Women in ministry: an egalitarian perspective. In Beck, J.R.,. ed. Two views on women in ministry. Rev. ed. Grand Rapids, Ml: Zondervan. p. 21-103).

Blackaby, H. \& Blackaby, R. (2011). Spiritual Leadership: moving people on to God's agenda. Nashville, TN: B \& H.

Blomberg, C.L. (2005). Women in ministry: a complementarian perspective. (In Beck, J.R., ed. Two views on women in ministry. Rev. ed. Grand Rapids, Ml: Zondervan. p. 121-184).

Breed, D.G., Van Rensburg, F.J. \& Jordaan, G.J.C. (2008). Male and Female in the church: gender in the ordained ministries. Potchefstroom, South Africa: Potchefstroom Theological Publications.

CCL see Center for Christian Leadership (CCL) at Dallas Theological Seminary. (2004). Integrity: examining how I live. Colorado Springs, CO: Navpress.

Clark, S. (2011). Research brief: intentional fathering. Journal of discipleship and family ministry 2(1), 44-45. Fall.

Danker, F.W., ed. (2000). A Greek-English lexicon of the New Testament and other early Christian literature. $3^{\text {rd }}$ ed., BDAG. Chicago, III: University of Chicago Press.

Finzel, H. (1994). The top ten mistakes leaders make. Wheaton, III: Victor Books.

Frame, J.M. (1991). Men and women in the image of God. In Grudem, W. \& Piper, J., eds. Recovering biblical manhood \& womanhood: a response to evangelical feminism. Wheaton III: Good News. p. 225-232. 
Freeks, F.E. \& Lotter, G.A. (2009). 'n Praktiese-teologiese ondersoek na die uitwerking van afwesige vaders: 'n verkennende kwalitatiewe ondersoek in die Promosa-gemeenskap. Koers, 74(3),519-534.

Freeks, F.E. (2011). The role of the father as mentor in the transmission of values: a pastoraltheological study. Potchefstroom, South Africa: North West University. (Thesis - PhD).

Freeks, F.E., Strydom C. \& Bartlett, E. (2015). Die impak van afwesige vaders op adolessente dogters se psigososiale welstand. Health SA gesondheid, 20(1), 45-58.

Garland, D.E. (2003). Baker exegetical commentary on the New Testament: 1 Corinthians. Grand Rapids, MI: Baker Academic.

Greenleaf, R.K. (1998). The power of servant leadership. San Francisco, CA: Berret-Koehler Publishers, Inc.

Grudem, W. (2006). Countering the claims of evangelical feminism: biblical responses to the key questions. Colorado Springs, CO: Multnomah ${ }^{\circledR}$.

Grudem, W. \& Piper, J. eds., (1991). Recovering biblical manhood \& womanhood: a response to evangelical feminism. Wheaton III: Good News.

Hamilton, D.J. (2000). The question of headship: part one of 1 Corinthians 11:2-16. In Cunningham, L., Hamilton, D.J. \& Rogers, J., eds. Why not women? A fresh look at Scripture on women in missions, ministry and leadership. Seattle, WA: YWAM. p. 159-175).

Hardenbrook, W. (1991). Where's dad? A call for fathers with the Spirit of Elijah. In Grudem, W. \& Piper, J., eds. Recovering biblical manhood \& womanhood: a response to evangelical feminism. Wheaton III: Good News. p. 378-387.

Hoehner, H.W. (2000). Ephesians. (In Walvoord, J.F. \& Zuck, R.B., eds. The Bible knowledge commentary: an exposition of the Scriptures by Dallas Seminary faculty. New Testament ed. - based on the New International Version. Colorado Springs, CO: Cook Communication Ministries. p. 613-645).

Hoehner, H.W. (2002). Ephesians: an exegetical commentary. Grand Rapids, MI: Baker Academic.

Hughes, R.K. (2006). Disciplines of a godly man. Vereeniging, South Africa: Christian Art.

Krampe, E.M. \& Newton, R.R. (2006). The father presence Questionnaire: A new measure of the subjective experience of being fathered. Fathering, 4(2),159-190, Spring.

Köstenberger, A.J. \& Köstenberger, M.E. (2014). God's design for man and woman: a biblical-theological survey. Wheaton, III: Crossway.

Liden, R.C., Wayne, S.J., Lioa, C. \& Meuser, J.D. (2014). Servant leadership and serving culture: influence on individual and unit performance. Academy of Management Journal, 57(5), 1434-1452.

MacArthur, J. (2008). The master's plan for the church. Chicago, III: Moody.

Malphurs, A. (2003). Being leaders: the nature of authentic Christian leadership. Grand Rapids, MI: Baker Books.

Malphurs, A. (2005). Advanced strategic planning: a new model for church ministry leaders. 2nd ed. Grand Rapids, MI: Baker Books. 
Marcoux, H. (2018). (June 13). Dads now spend 3 times as much time with their kids than previous generations. Motherly. https://www.mother.ly. Date of access: 2 Jan. 2020.

Masongo, M.A. (2020). Effectiveness of WhatsApp homiletics in the era of COVID-19 in South Africa. Pharos Journal of Theology. Vol. 101, Online @ http//:www.pharosjot.com. Date of Access: 8 Feb. 2021.

Maxwell J.C. (1993). Developing the leader within you. Nashville, TN: Thomas Nelson.

Maxwell J.C. (1995). Developing the leaders around you. Nashville, TN: Thomas Nelson.

Morley, P. \& Delk, D. (2004). The dad in the mirror: how to see your heart for God reflected in your children. Cape Town: Struik Christian Books.

Neuer, W. (1991). Man and woman in Christian perspective. Wheaton, III: Crossway Books.

Ngaruiya, D.K. (2017). Characteristics of influential African Christian leaders. In Barine, K. \& Priest, J., eds. African Christian leadership: realities, opportunities, and impact. Maryknoll, NY: Orbis Books. p. 29-47.

Ortlund, R.C., Jr. (1991). Male-female equality and male headship Genesis 1-3. In Grudem, W. \& Piper, J., eds. Recovering Biblical manhood \& womanhood: a response to evangelical feminism. Wheaton III: Good News. p. 95-112.

Osmer, R.R. (2008). Practical theology: an introduction. Grand Rapids, MI: WB Eerdmans.

Padi, T., Kholopane, P., Khunou, G. \& Nduna, M. (2014). Defining absent, unknown and undisclosed fathers in South Africa. South African review of sociology, 45(2), 44-59.

Payne, P.B. (2012). Does the New Testament name only men as local church officers? Pricilla papers, 26(3), 5-6. Summer.

Sanders, J.O. (1994). Spiritual leadership: principles of excellence for every believer. Chicago, IL: Moody Press.

Schreiner, T.R. (2005). Women in ministry: another complementarian perspective. (In Beck, J.R., ed. Two views on women in ministry. Rev. ed. Grand Rapids, Ml: Zondervan. p. 263322).

Shahvisi, A. (2019). "Men are trash": The surprisingly philosophical story behind an internet punchline. Prospect Magazine, August 2019.

Smith, K.G. (2013). Bible reading practices in South Africa: a report by the South African Theological Seminary. Johannesburg: South African Theological Press.

Snodgrass, K. (1996). Ephesians: the NIV application commentary, from biblical text to contemporary life. Grand Rapids, MI: Zondervan.

Spears, L.C. (2010). Character and servant leadership: ten characteristics of effective, caring leaders. The Journal of Virtues \& Leadership, 1(1),25-30.

Strauch, A. (1995). Biblical eldership: an urgent call to restore biblical church leadership. Revised and expanded. Littleton, CO: Lewis and Roth.

Stringer, D. (2009). Hope for a fatherless generation: rebuilding our foundations.

Shippingsburg, PA: Destiny Image. 
Thielman, F. (2010). Baker exegetical commentary on the New Testament-ECNT: Ephesians. Grand Rapids, MI: Baker Academic.

Verster, P. 2020. A theological engagement with the COVID-19 pandemic. Pharos Journal of Theology. Vol. 101, Online @ http//:www.pharosjot.com. Date of Access: 11 Feb. 2021.

Warren, R.C. (2005). Our fathers who are on earth: if Satan thinks they are a key battleground, shouldn't we? Christianity Today, 49(5),53.

Wiersbe, W.W. (2011). On being a leader for God. Grand Rapids, MI: Baker Books.

Williams, A. (2008). We badly need good fathers. Human Events, 64(21), 506, June. 